\title{
Characterization of Quisqualate Receptor Desensitization in Cultured Postnatal Rat Hippocampal Neurons
}

\author{
Liu Lin Thio, David B. Clifford, and Charles F. Zorumski \\ Departments of Psychiatry, and Anatomy and Neurobiology, Washington University School of Medicine, St. Louis, \\ Missouri 63110
}

The quisqualate class of glutamate receptors is thought to play an important role in excitatory synaptic transmission, synaptic plasticity, and neuronal death. Since desensitization is a prominent feature of the responses mediated by this class of receptors, we have characterized the rapidly desensitizing quisqualate response in cultured postnatal rat hippocampal neurons using the whole-cell patch-clamp technique. Quisqualate and its structural analogs elicit a peak current that rapidly decays to a steady-state level. In contrast, currents induced by kainate, NMDA, and their structural analogs exhibit either no decay or a much slower decay. The biophysical and pharmacological properties of the peak and steady-state quisqualate currents indicate that both are mediated by an ionotropic quisqualate receptor.

Quisqualate currents desensitized monoexponentially by $\sim 70 \%$ with a time constant near $80 \mathrm{msec}$. Both the rate and percentage of desensitization showed slight voltage dependence and were concentration dependent, reaching maximal values at saturation. Additionally, the overlap of the doseresponse curves for activation of the steady-state current and desensitization of the peak current by a conditioning dose suggests that the two processes are related. Furthermore, desensitizing quisqualate currents were observed when $\mathrm{Ca}^{2+}, \mathrm{Mg}^{2+}, \mathrm{Na}^{+}, \mathrm{K}^{+}$, and $\mathrm{Cl}^{-}$were removed from the extracellular solution or their concentrations greatly reduced. These results suggest that the decline in the response is not caused by a simple open channel block mechanism.

Despite the lack of desensitization by kainate, our observations are consistent with the hypothesis that quisqualate and kainate act at a single receptor-channel complex. Kainate and quisqualate appeared to interact competitively when applied simultaneously and noncompetitively when quisqualate was applied first. In addition, saturating doses of quisqualate and kainate gave steady-state currents of equal amplitude in neurons treated with the lectin WGA, an inhibitor of quisqualate receptor desensitization.

Received Mar. 25, 1991; revised May 24, 1991; accepted June 6, 1991.

This work was supported by Physician Scientist Award MH00630, Medical Scientist Research Service Award GM07200, and Grants MH45493 and AG05681 from the National Institutes of Health. This work was also supported by the Klingenstein and Bantly Foundations.

Correspondence should be addressed to Charles F. Zorumski, M.D., Washington University School of Medicine, Department of Psychiatry, 4940 Audubon Avenue, St. Louis, MO 63110.

Copyright (C) 1991 Society for Neuroscience $0270-6474 / 91 / 113430-12 \$ 05.00 / 0$
Excitatory neurotransmission in the vertebrate CNS is believed to result primarily from the release of glutamatc and the subsequent activation of excitatory amino acid receptors (Mayer and Westbrook, 1987; Collingridge and Lester, 1989). In addition to mediating excitatory synaptic transmission, these receptors also are thought to be involved in both synaptic plasticity and neuronal death, processes that are important during normal development and that may be involved in the pathogenesis of some CNS disorders (Choi, 1988; Collingridge and Singer, 1990; McDonald and Johnston, 1990; Meldrum and Garthwaite, 1990). These actions are mediated by three of the major classes of excitatory amino acid receptors that are defined by structural analogs of glutamate: NMDA, kainate, and quisqualate. All three receptors are linked to nonselective cationic channels (Mayer and Westbrook, 1987; Collingridge and Lester, 1989) and activate second messenger systems (Smart, 1989). In the case of quisqualate, two different receptors appear to existonc linked to an ion channel and another linked to the phosphoinositide second messenger system (Monaghan et al., 1989; Watkins et al., 1990). In this study, we have focused on the ion channel-coupled quisqualate receptor in cultured postnatal rat hippocampal neurons.

Ionotropic quisqualate receptors are thought to mediate fast excitatory synaptic transmission in the vertebrate CNS (Mayer and Westbrook, 1987; Collingridge and Lester, 1989). The postsynaptic response evoked by activation of these receptors is increased during long-term potentiation (LTP) in the hippocampus (Kauer et al., 1988; Muller and Lynch, 1988; Muller et al., 1988; Davies et al., 1989), while it is decreased during longterm depression (LTD) in the cerebellum (Kano and Kato, 1987). These two phenomena are often considered to be physiological correlates of learning and memory (Thompson, 1986). Activation of quisqualate-gated ion channels for prolonged periods can also result in neuronal death in vitro and in vivo (Choi, 1988; McDonald and Johnston, 1990; Meldrum and Garthwaite, 1990). Thus, the ionotropic quisqualate receptor, in particular, is likely to be involved in both normal and pathological processes.

Recent studies indicate that quisqualate receptors mediate rapidly and profoundly desensitizing responses in neurons from the rodent hippocampus (Kiskin et al., 1986; Trussell et al., 1988; Mayer and Vyklicky, 1989; Tang et al., 1989; Patneau and Mayer, 1990), chick spinal cord (Vlachová et al., 1987; Trussell et al., 1988; Trussell and Fischbach, 1989; Baev et al., 1990), goldfish retina (Ishida and Neyton, 1985), stingray retina (O'Dell and Christensen, 1989a), catfish retina (O'Dell and Christensen, 1989b), rat superior colliculus (Perouansky and Grantyn, 1989), and rat dorsal root ganglion (Huettner, 1990) 
as wcll as rat O-2A glial progenitor cells (Barres et al., 1990). These responses desensitize with time constants as fast as $3 \mathrm{msec}$ and by as much as $95 \%$ of their peak amplitude (Tang et al., 1989; Trussell and Fischbach, 1989). Although the physiological role of ligand-gated ion channel desensitization is not clear, it may protect cells from the effects of repeated receptor activation, and it may serve to regulate synaptic efficacy (Ochoa et al., 1989). For example, cerebellar LTD may be a manifestation of quisqualate receptor desensitization (Ito, 1986; Kano and Kato, 1987). Given the ubiquity of rapidly desensitizing quisqualate responses and the potential physiological importance of desensitization, we have characterized the rapidly desensitizing quisqualate current in cultured postnatal rat hippocampal neurons using the whole-cell patch-clamp technique.

Some of these results have been presented previously in a preliminary form (Thio et al., 1988).

\section{Materials and Methods}

Postnatal rat hippocampal cell cultures. Hippocampal cells were cultured from 1-3 d postnatal Sprague-Dawley (Washington University Department of Psychiatry strain) rats as described previously (Trussell et al., 1988). Briefly, hippocampal slices were enzymatically digested with $1 \mathrm{mg} / \mathrm{ml}$ papain in Leibovitz's L-15 media for 20-30 min. Slices were then mechanically dissociated into single cells by gentle trituration in culture media containing $5 \%$ or $10 \%(\mathrm{v} / \mathrm{v})$ horse serum, $5 \%$ or $10 \%(\mathrm{v} /$ v) fetal calf serum, $17 \mathrm{mM}$ D-glucose, $200 \mu \mathrm{M}$ or $400 \mu \mathrm{M}$ glutamine, 50 $\mathrm{U} / \mathrm{ml}$ penicillin, and $50 \mu \mathrm{g} / \mathrm{ml}$ streptomycin. The cells were plated in culture media on collagen-coated dishes or on a glial feeder layer obtained from platings in which the neurons were permitted to die. The cells were studied after being incubated in a humidified $95 \%$ air, $5 \%$ $\mathrm{CO}_{2}$ atmosphere at $37^{\circ} \mathrm{C}$ for $2-4 \mathrm{hr}$ if plated on a glial feeder layer or for 3-7 d if plated on collagen.

Whole-cell electrophysiology. Voltage-clamp experiments were conducted at room temperature $\left(22-24^{\circ} \mathrm{C}\right.$ ) with an EPC-7 (Adams and List Associates, Lid., Great Neck, NY) or Axopalch-1D (Axon Instruments, Foster City, CA) amplifier using the whole-cell patch-clamp technique (Hamill et al., 1981). The cells were bathed in an extracellular solution containing (in mM) $140 \mathrm{NaCl}, 5 \mathrm{KCl}, 3 \mathrm{CaCl}_{2}, 1 \mathrm{MgCl}_{2}, 10 \mathrm{D}$-glucose, 0.001 tetrodotoxin, and $10 N$-[2-hydroxyethyl]piperazine- $N^{\prime}$-[2-ethanesulfonic acid] (HEPES) (pH 7.3). Any modifications to the extracellular solution are noted in the text. Drugs were dissolved in the solution bathing the cells unless otherwise noted and were applied rapidly with the pressure ejection system described previously (Trussell et al., 1988). This system permitted solution changes at the tip of an electrode located $10-20 \mu \mathrm{m}$ away from the drug delivery pipette to occur with a time constant of $8.3 \pm 1.6 \mathrm{msec}(n=6)$ as measured by a change in junction potential. In whole-cell recordings, the drug delivery pipette was positioned within $\sim 2 \mu \mathrm{m}$ of the cell soma.

Patch electrodes were pulled from borosilicate glass (World Precision Instruments, Inc., Sarasota, FL) and had resistances of 5-10 M $\Omega$ when filled with a solution containing (in mM) $140 \mathrm{CsCl}, 4 \mathrm{NaCl}, 0.5 \mathrm{CaCl}_{2}$, 5 ethylene glycol bis $\left(\beta\right.$-aminoethyl)ether- $N, N, N^{\prime}, N^{\prime}$-tetraacetic acid (EGTA), and $10 \mathrm{HEPES}$ (pH 7.3). In some recordings, $140 \mathrm{CsCl}$ was replaced with $140 \mathrm{Cs}$ acetate, $120 \mathrm{CsCl}$ plus 20 tetraethylammonium (TEA) $\mathrm{Cl}, 140 \mathrm{~K}$-gluconate, or $70 \mathrm{Cs}_{2} \mathrm{SO}_{4}$ plus 70 sucrose. When a lower $\mathrm{Ca}^{2+}$ buffering capacity was desired, the pipettes were filled with a solution composed of (in $\mathrm{mM}$ ) $140 \mathrm{KCl}, 4 \mathrm{NaCl}, 0.5 \mathrm{EGTA}$, and $10 \mathrm{HEPES}$ (pH 7.3). Any further modifications of the $140 \mathrm{mM} \mathrm{CsCl}$ pipette solution are given in the text, though this solution was used with the composition first listed for most experiments.

Earlier studies showed that neurons cultured for several hours to $7 \mathrm{~d}$ had resting membrane potentials of -50 to $-60 \mathrm{mV}$ and fired overshooting action potentials. Their input resistances decreased with time in culture ranging from $2250 \mathrm{M} \Omega$ after $2-4 \mathrm{hr}$ in culture to $500 \mathrm{M} \Omega$ after $7 \mathrm{~d}$ in culture. In this study, the neurons were voltage clamped at -50 $\mathrm{mV}$ except as indicated. Usually, the series resistance compensation was set at $50 \%$ while the cell and pipette capacitance were maximally compensated. Current records were passed through a $1 \mathrm{kHz}(-3 \mathrm{~dB}) 8$-pole low-pass Bessel filter (Frequency Devices, Haverhill, MA) before being stored with a Gould model 220 recorder (Gould Electronics, Cleveland,
$\mathrm{OH}$ ) or digitized at 1 or $2 \mathrm{kHz}$ with pCLAMP version 4.0-5.5 (Axon Instruments).

Data analysis. Data were analyzed off line using pCLAMP version 4.05.5, ASYSTANT version 1.0-1.1 (Asyst Software Technologies, Inc., Rochester, NY), and SIGMAPLot version 4.0 (Jandel Scientific, Corte Madera, CA). Results are given as the mean \pm standard error of the mean (SEM) ( $n=$ number of neurons) and were compared using a two-tailed $t$ test. The Hill coefficient is reported as the slope of the line \pm standard deviation obtained by fitting a plot of

$$
\log \frac{\% \text { maximum response }}{\text { maximum response }-\% \text { maximum response }} \text { versus } \log [\mathrm{drug}]
$$

by linear regression.

Materials. Culture media, sera, and antibiotics were purchased from GIBCO BRL Life Technologies, Inc. (Gaithersburg, MD). All other chemicals were purchased from Sigma Chemical Company (St. Louis, MO) except Cs acetate (Aldrich Chemical Company, Inc., Milwaukee, WI) and some excitatory amino acid agonists and antagonists. Quisqualate, $\alpha$-amino-3-hydroxy-5-methyl-4-isoxazolepropionic acid (AMPA), $\beta$ - $N$-oxalylamino-r -alanine (BOAA), and D-2-amino-5-phosphonovaleric acid (D-APV) were from Cambridge Research Biochemicals, Inc. (Wilmington, DE). $\alpha$-Amino-3-hydroxy-4-methyl-5-isoxazolepropionic acid (4-methyl-homoibotenic acid), willardiine, 5-bromowillardiine, dihydrokainate, trans-( \pm -1-aminocyclopentane1,3-dicarboxylic acid (trans-ACPD), L-homocysteine sulphinic acid (L-HCSA), 6-cyano-7-nitroquinoxaline-2,3-dione (CNQX), and 3-(( \pm )2-carboxypiperazin-4-yl)propyl-1-phosphonic acid (CPP) were from Tocris Neuramin Ltd. (Essex, England).

\section{Results}

Quisqualate and its congeners evoke a rapidly decaying current Similar to previous studies (Kiskin et al., 1986; Trussell et al., 1988; Mayer and Vyklicky, 1989; Tang et al., 1989; Patneau and Mayer, 1990), glutamate and some non-NMDA but no NMDA agonists clicitcd rapidly decaying currents in hippocampal neurons. The non-NMDA agonists that activated such currents included quisqualate $(10-1000 \mu \mathrm{M})$, AMPA (1 $\mathrm{mM})$, 4-methyl-homoibotenic acid (1 mM), BOAA (1 mM), willardiine (0.5-1 mM), and 5-bromowillardiine (1 mM) (Figs. 1 $A, 2 A$ ). All these agonists either appear to act at quisqualate receptors or are structurally similar to quisqualate (Watkins et al., 1990). Non-NMDA agonists that activated nondesensitizing currents included kainate $(0.05-10 \mathrm{mM})$ as well as two structural relatives of kainate, domoate (0.1-1 $\mathrm{mm}$ ) and dihydrokainate (1 $\mathrm{mm}$ ) (Fig. 1B). Trans-ACPD, an agonist selective for the metabotropic quisqualate receptor (Watkins et al., 1990), did not elicit a current over the voltage range from -80 to $+20 \mathrm{mV}$ using the $\mathrm{KCl}$ pipette solution with a low $\mathrm{Ca}^{2+}$ buffering capacity. Although currents elicited by NMDA decayed during a sustained application, they decayed along a much slower time course than currents produccd by glutamate or quisqualate (Clark et al., 1990). Other NMDA agonists include L-aspartate (1 mM), ibotenate (1 mM), D-homocysteic acid (1 mM), L-homocysteic acid (1 mM), L-HCSA (1 mM), and threo- $\beta$-hydroxyaspartate (1 mM) (Watkins et al., 1990), all of which did not evoke a rapidly decaying current (Fig. 1C).

\section{Current-voltage relationship for the quisqualate current}

The peak quisqualate current had a reversal potential of -0.6 $\pm 0.8 \mathrm{mV}(n=18)$ as determined from current-voltage $(I / V)$ plots generated by voltage-clamping neurons at various potentials and applying $100 \mu \mathrm{M}$ quisqualate ("steady-state $I / V$ ") (Fig. $2 A, B)$. The steady-state current had a reversal potential of -1.3 $\pm 1.2 \mathrm{mV}(n=18)$ when measured from a steady-state $I / V$ (Fig. $2 A, C)$ and a reversal potential of $+4.9 \pm 0.9 \mathrm{mV}(n=12)$ when calculated from $I / V$ plots obtained by subjecting a neuron to a 
A
AMPA

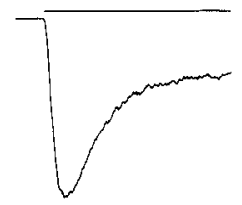

B

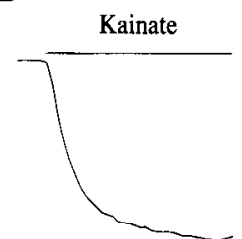

C

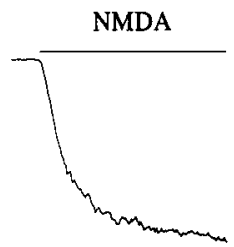

4-Methyl-homoibotenate
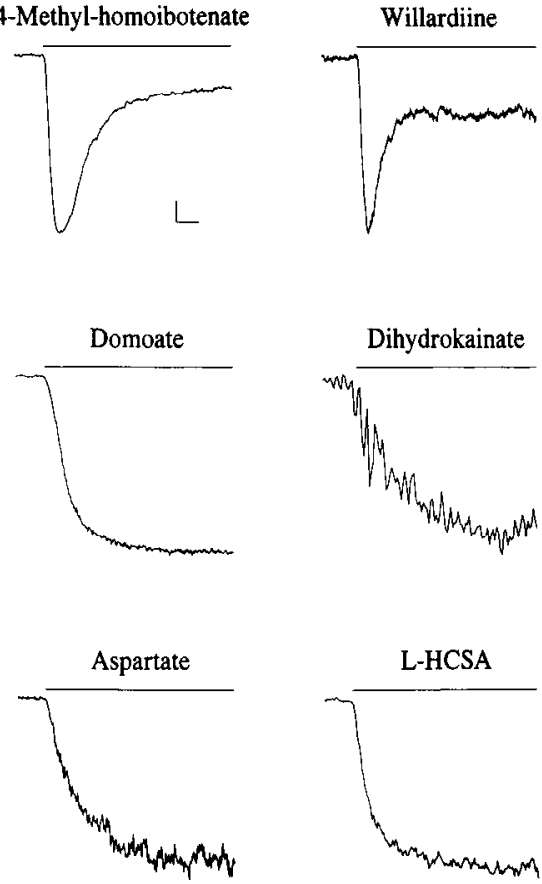

Figure 1. Excitatory amino acids related to quisqualate $(A)$ elicited rapidly decaying currents while those related to kainate $(B)$ and NMDA $(C)$ did not: responses of neurons at a holding potential of $-50 \mathrm{mV}$ to $1 \mathrm{~mm}$ of each agonist. Bars above traces in all figures denote period of drug application. Vertical calibration: $130 \mathrm{pA}$ (AMPA), $56 \mathrm{pA}$ (4-methyl-homoibotenic acid), $33 \mathrm{pA}$ (willardiine), $100 \mathrm{pA}$ (kainate), $50 \mathrm{pA}$ (domoate), $26 \mathrm{pA}$ (dihydrokainate), $70 \mathrm{pA}$ (NMDA), $26 \mathrm{pA}$ (L-aspartate), $50 \mathrm{pA}$ (L-HCSA). Horizontal calibration; $60 \mathrm{msec}$.

voltage step protocol during a sustained application of $100 \mu \mathrm{M}$ quisqualate ("instantaneous $I / V$ ") (Fig. $2 C$ ). Although these experiments were performed using pipette solutions containing $145 \mathrm{mM} \mathrm{Cl}^{-}$, decreasing the $\mathrm{Cl}^{-}$concentration did not significantly alter the reversal potential of either component. When the concentration of chloride ions in the pipette was reduced from 145 to $5 \mathrm{~mm}$, the reversal potential for the peak current was $+2.3 \pm 1.0 \mathrm{mV}(n=9)$ and that for the steady-state current was $-2.0 \pm 2.2 \mathrm{mV}(n=9)$. These results indicate that both components of the quisqualate response are mediated by a nonselective cationic conductance and that the decay of the current does not result from a redistribution of ions.

The decay in the quisqualate current at positive holding potentials indicates that the decay at negative holding potentials does not reflect the activation of an inward current followed by a more slowly activating outward current. The outward current would be mediated by $\mathrm{K}^{+}$or $\mathrm{Cs}^{+}$under the ionic conditions used. However, if the decay in the quisqualate response at negative holding potentials were caused by the sequential activation of an inward and an outward current, then no decay would be apparent at positive holding potentials as both currents would be outward.

The peak quisqualate current had a linear $I / V$ relationship (Fig. $2 B$ ), while the linearity of the $I / V$ relationship for the steady-state current was dependent on the protocol employed. The instantaneous $I / V$ relationship for the steady-state current was nearly linear, whereas the steady-state $I / V$ relationship was not (Fig. 2C). This observation was quantified by calculating the ratio of the absolute value of the steady-state current mag- nitude at $+50 \mathrm{mV}$ to that at $-90 \mathrm{mV}$. This ratio was $1.0 \pm 0.1$ $(n=15)$ in the steady-state $I / V$ curves. In contrast, it was 0.5 $\pm 0.1(n=9$; two-tailed $t$ test, $p<0.01)$ in the instantaneous $I / V$ relationship as would be expected for a nearly linear relationship with a reversal potential near $0 \mathrm{mV}$. The nonlinearity of the steady-state $I / V$ curve cannot be ascribed to the activation of NMDA receptors since similar results were obtained in the presence of $0.5 \mathrm{~mm} \mathrm{D,L-APV}$, and D-APV did not affect the steady-state current (see below). Furthermore, the $I / V$ curve for NMDA currents generated by a voltage step protocol is nonlinear in the presence of extracellular $\mathrm{Mg}^{2+}$ in mouse spinal cord neurons because of the rapidity of the $\mathrm{Mg}^{2+}$ block (Mayer and Westbrook, 1985).

\section{Concentration dependence of the quisqualate current}

Both the peak and steady-state currents were evoked by quisqualate in a concentration-dependent manner (Fig. $3 A, B$ ). The dose-response curves were generated by normalizing the amplitudes of the peak and steady-state currents evoked by a test concentration of quisqualate to those elicited by $100 \mu \mathrm{M}$ in a single neuron. Postnatal rat hippocampal neurons began to show a clear albeit nondecaying response to concentrations near 100 nM. A decaying current was elicited at $\sim 10 \mu \mathrm{M}$, which was close to saturation for the steady-state current. The dose-response curve for the peak current, in contrast, saturated at $\sim 300 \mu \mathrm{M}$. Half-maximal activation for the peak $\left(\mathrm{ED}_{50 \text { (pcak })}\right)$ and steady-state $\left(E_{50(s s)}\right)$ currents occurred at 40 and $3 \mu \mathrm{M}$, respectively. Hill plots gave a Hill coefficient of $0.9 \pm 0.04$ for the peak current and $0.8 \pm 0.1$ for the steady-state current (Fig. 3C).

\section{Activation of a non-NMDA receptor-ion channel complex produces the quisqualate current}

The ability of non-NMDA but not NMDA agonists to evoke a rapidly decaying current strongly suggests that a non-NMDA rather than an NMDA receptor-channel complex is involved. Accordingly, the nonspecific excitatory amino acid antagonist (Collingridge and Lester, 1989) kynurenic acid at 1 and $10 \mathrm{~mm}$ reversibly reduced the peak current evoked by $100 \mu \mathrm{M}$ quisqualate by $31 \pm 6 \%(n=4)$ and $69 \pm 6 \%(n=5)$. Neither concentration of kynurenic acid was effective at antagonizing the steady-state current produced by $100 \mu \mathrm{M}$ quisqualate. Furthermore, $10 \mu \mathrm{M}$ CNQX, a competitive non-NMDA antagonist (Collingridge and Lester, 1989), reversibly inhibited the peak current elicited by $100 \mu \mathrm{M}$ quisqualate by $46 \pm 5 \%(n=11)$ without affecting the steady-state current (Fig. 4A). The steadystate current evoked by $10 \mu \mathrm{M}$ quisqualate, however, was reversibly blocked by $53 \pm 6 \%(n=19)$ by $10 \mu \mathrm{M}$ CNQX (Fig. $4 B$ ). Dose-response curves for the peak and steady-state currents in the presence of $10 \mu \mathrm{M} C \mathrm{NQX}$ were shifted to the right with no change in the maximum response as expected of a competitive antagonist (Fig. $4 C, D$ ). The $\mathrm{ED}_{50(\text { peak, } C N Q x)}$ and

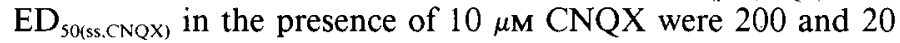
$\mu \mathrm{M}$, respectively. The competitive NMDA antagonists $\mathrm{D}-\mathrm{APV}$ and CPP did not inhibit either component of the response produced by $100 \mu \mathrm{M}$ quisqualate (Fig. $4 E$ ). The peak and steadystate currents were $100 \pm 6 \%(n=7)$ and $100 \pm 4 \%(n=7)$, respectively, of control in the presence of $1 \mathrm{~mm} \mathrm{D-APV}$. The corresponding values in the presence of $1 \mathrm{~mm}$ CPP were $110 \pm$ $4 \%(n=7)$ and $100 \pm 3 \%(n=7)$. The steady-state current elicited by $10 \mu \mathrm{M}$ quisqualate also was equal to control in the presence of $1 \mathrm{mM}$ D-APV $(n=11)$.

These results together indicate that the rapidly decaying quis- 
A

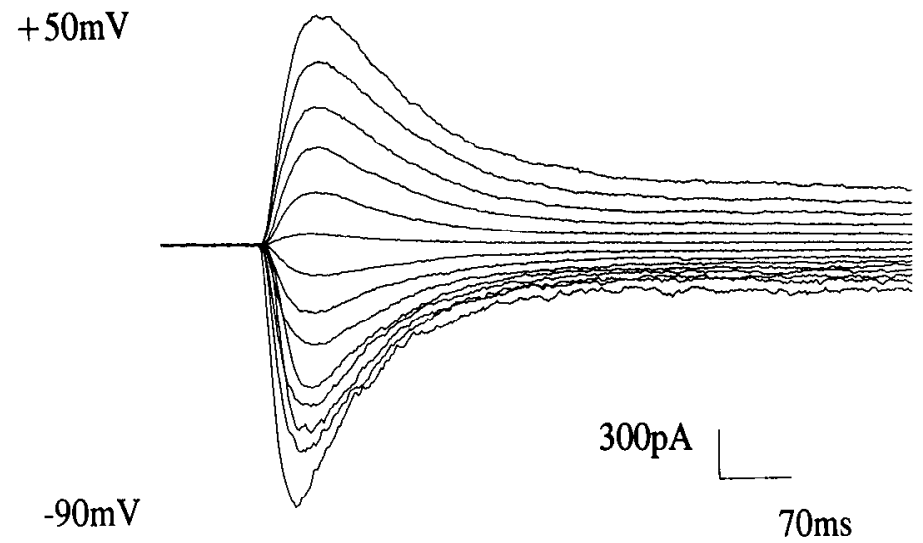

B

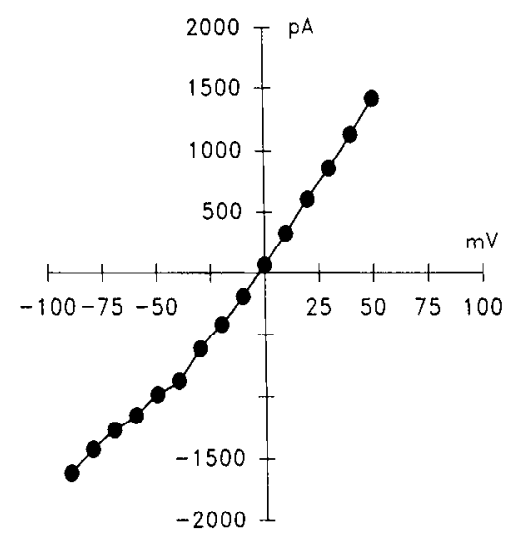

C

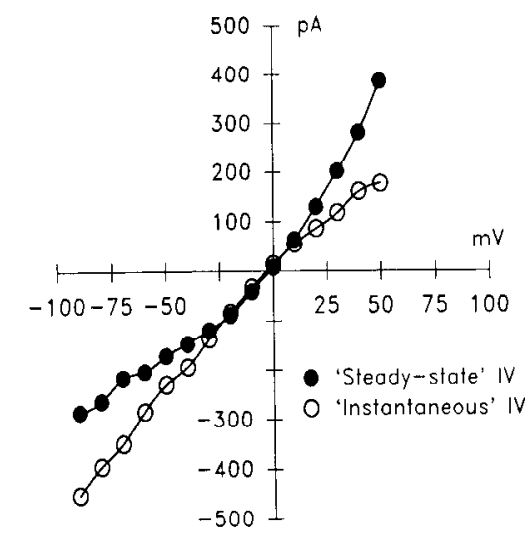

Figure 2. I/V relationship for the peak and steady-state quisqualate currents. $A$, Responses of a neuron to $500 \mathrm{msec}$ applications of $100 \mu \mathrm{M}$ quisqualate at voltages between -90 and $+50 \mathrm{mV}$ in $10 \mathrm{mV}$ increments. The neuron was bathed in an extracellular solution supplemented with $200 \mu \mathrm{M} \mathrm{CdCl}_{2}$ and 500 $\mu_{\mathrm{M}} \mathrm{D}, \mathrm{L}-\mathrm{APV}$. The $-80 \mathrm{mV}$ trace was omitted for clarity. $B, I / V$ relationship for the peak quisqualate current. The peak current amplitudes for the traces in $A$ were plotted against voltage. $C$, "Steady-state" (solid circles) and "instantaneous" (open circles) $I / V$ relationships for the steady-state current. The "steady-state $I / V$ " relationship is a plot of the steady-state current amplitude versus holding potential using the data in $A$. The data for the "instantaneous $I / V$ " were obtained by subjecting the neuron in $A$ to a series of voltage steps before and during the steady-state current produced by a prolonged application of $100 \mu \mathrm{M}$ quisqualate. The steps were $60 \mathrm{msec}$ in duration and altered the potential from -90 to $+50 \mathrm{mV}$ in $10 \mathrm{mV}$ increments. The steady-state current magnitude at each voltage during the voltage step protocol was determined after subtracting the control records from the records taken during the quisqualate application. qualate current results from desensitization rather than an inadequate spatial voltage clamp, a redistribution of ions, or the sum of two opposing currents. The decline in the current does not result from an inadequate spatial voltage clamp because the decline was evident in the presence of tetrodotoxin, cesium, TEA, and cadmium. In addition, the decay was present in acutely dissociated neurons, defined as neurons cultured for 2-4 hr. Such neurons have input resistances near $2 \mathrm{G} \Omega$ and charging curves well described by a single exponential. The decay in the response also is not caused by enzymatic modification of the receptor-channel complex, as the response in cells dissociated nonenzymatically by mechanical trituration alone exhibited a rapidly decaying quisqualate response.

\section{Characteristics of quisqualate receptor desensitization}

When quisqualate currents desensitized, they did so along a monoexponential time course at all voltages and concentrations tested (Fig. 5A). The time constant of desensitization $\left(\tau_{d}\right)$ increased slightly with depolarization and was longer for 10-20 $\mu \mathrm{M}$ quisqualate than for concentrations above $25 \mu \mathrm{M}$ (Fig. $5 B, C$ ). The percent desensitization, calculated by

$$
\% \text { desensitization }=\frac{\text { peak current }- \text { steady-state current }}{\text { pcak current }- \text { baseline current }},
$$

was dependent on quisqualate concentration and was slightly dependent on voltage (Fig. $5 D$ ). The percent desensitization reached maximal values at saturating concentrations for the peak current.

The proportion of receptors desensitized by a given concentration was estimated by measuring the extent to which a conditioning dose reduced the peak current evoked by $100 \mu \mathrm{M}$. Conditioning doses of $\geq 10 \mathrm{nM}$ reduced the peak current induced by $100 \mu \mathrm{M}$ quisqualate in a concentration-dependent manner (Fig. 6). The decrease in the peak current was augmented as the conditioning dose increased, with a conditioning dose of $10 \mu \mathrm{M}$ producing a nearly maximal effect and $1 \mu \mathrm{M}$ giving a half-maximal effect (ED (E(ss desensitization) $_{\text {) }}$ (Fig. $\left.6 A, B\right)$. Thus, the percentage of receptors desensitized by a given concentration of quisqualate correlates with its ability to activate the steady-state current, meaning that the dose-response curves for the steady-state current and the desensitization induced by a conditioning dose overlap. Both curves have a similar $\mathrm{ED}_{50}$, and both rise and saturate at comparable concentrations. However, it should be noted that conditioning doses of 10 and $50 \mathrm{~nm}$ desensitized $\sim 10 \%$ of the receptors in some neurons showing no detectable macroscopic response to these concentrations (Fig. 6C).

\section{Ionic requirements of quisqualate receptor desensitization}

Quisqualate receptor desensitization did not require the presence of extracellular $\mathrm{Ca}^{2+}, \mathrm{Mg}^{2+}, \mathrm{Na}^{+}$, or $\mathrm{K}^{+}$(Fig. 7). In the nominal absence of both $\mathrm{Ca}^{2+}$ and $\mathrm{Mg}^{2+}, \tau_{d}$ and the \% desen- 
A

Figure 3. Concentration dependence of the peak and steady-state quisqualate currents. $A$, Responses of a neuron voltage clamped at $-50 \mathrm{mV}$ to $0.5,25$, and $100 \mu \mathrm{M}$ quisqualate. $B$, Dose-response curves for the peak and steady-state quisqualate currents. Data points were obtained by normalizing the amplitude of the current elicited by a test quisqualate concentration to that elicited by $100 \mu \mathrm{M}$ quisqualate in a single neuron at a holding potential of $-50 \mathrm{mV}$. The raw data for the peak (solid circles) and steady-state (open circles) currents were visually fit to the curves shown. The visual fit for the peak current (solid curve) gave an $\mathrm{ED}_{\text {so(peak) }}$ of $40 \mu \mathrm{M}$, while the visual fit for the steady-state current (broken curve) gave an $\mathrm{ED}_{50(\mathrm{ss})}$ of $3 \mu \mathrm{M}$. Error bars depict \pm SEM, and those not shown are smaller than the symbol ( $n$ $=5-29$ for each point). $C$. Hill plots for peak and steady-state quisqualate currents obtained using the mean percent maximum response values in $B$. The raw data for the peak (solid circles) and steady-state (open circles) were fit to lines (solid line for peak, broken line for steady-state) having respective slopes of $0.9 \pm 0.04$ and $0.8 \pm 0.1$, respectively.

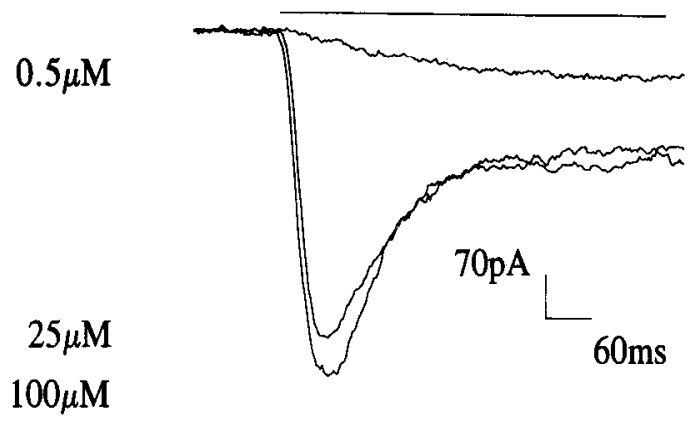

B

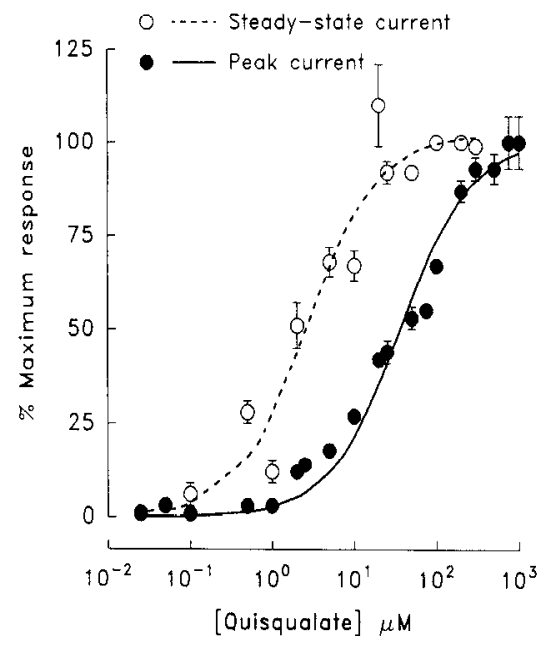

sitization were similar to those found in the presence of both cations when examined in the same neuron (Fig. 7A, Table 1). Furthermore, the dependence of these two parameters on voltage and quisqualate concentration was similar in the presence and nominal absence of $\mathrm{Mg}^{2+}$, confirming that an NMDA conductance was not contributing significantly to the quisqualate current (Fig. $7 D, E$ ). The voltage and concentration dependence of both parameters in the nominal absence of $\mathrm{K}^{+}$in the extracellular solution and $\mathrm{Cs}^{+}$in the pipette solution was also similar to those observed under control conditions (Fig. $7 B, F, G$ ). In addition, a rapidly desensitizing quisqualate receptor-mediated

\begin{tabular}{|c|c|c|c|}
\hline $\begin{array}{l}{\left[\mathrm{Ca}^{2+}\right]} \\
(\mathrm{mM})\end{array}$ & $\begin{array}{l}{\left[\mathrm{Mg}^{2+}\right]} \\
(\mathrm{mM})\end{array}$ & $\begin{array}{l}\text { Percent } \\
\text { desensitization } \\
(\text { mean } \pm \text { SEM) }\end{array}$ & $\begin{array}{l}\tau_{d} \\
(\mathrm{msec} ; \text { mean } \pm \mathrm{SEM})\end{array}$ \\
\hline 0 & 0 & $67 \pm 3(5)$ & $87 \pm 4(5)$ \\
\hline 3 & 0 & $64 \pm 6(5)$ & $80 \pm 11(5)$ \\
\hline 3 & 1 & $67 \pm 4(5)$ & $81 \pm 10(5)$ \\
\hline
\end{tabular}

Neurons voltage clamped at $-50 \mathrm{mV}$ were bathed in an extracellular solution containing no added $\mathrm{Ca}^{2+}$ and $\mathrm{Mg}^{2+}$ and were exposed to $100 \mu \mathrm{M}$ quisqualate in the presence of different concentrations of $\mathrm{Ca}^{2+}$ and $\mathrm{Mg}^{2+}$. The extracellular solution also contained $200 \mu \mathrm{M}$ D,L-APV to prevent neuronal swelling that normally occurs in the absence of divalent cations (L. L. Thio, D. B. Clifford, and C. F. Zorumski, unpublished observations). current qualitatively similar to control currents was observed when (1) the extracellular solution containcd no added $\mathrm{Ca}^{2+}$ and $10 \mathrm{mM} \mathrm{Mg}^{2+}$, (2) the extracellular solution contained $10 \mathrm{~mm}$ $\mathrm{Ca}^{2+}$ and no added $\mathrm{Mg}^{2+}$, (3) the only monovalent cation in the pipette and extracellular solutions was $\mathrm{Cs}^{+}$(Fig. 7C), (4) the $\left[\mathrm{Cl}^{-}\right]$in the extracellular and pipette solutions was reduced to $5 \mathrm{~mm}$, and (5) the buffer in the pipette and extracellular solutions was 3-[N-morpholino]propanesulfonic acid (MOPS) or Na$\mathrm{H}_{2} \mathrm{PO}_{4}$ instead of HEPES.

\section{Interaction between non-NMDA analogs}

Non-NMDA analogs that elicited a rapidly desensitizing current interacted with each other and with non-NMDA analogs that elicited a nondesensitizing current. The non-NMDA analogs that evoked a desensitizing current cross-desensitized the response to quisqualate. Specifically, an application of $100 \mu \mathrm{M}$ quisqualate during the steady-state current induced by glutamate (1 mM), AMPA (1 mM), BOAA (1 mM), 4-mcthyl-homoibotenic acid (1 $\mathrm{mM})$, willardiine (1 $\mathrm{mM})$, and 5-bromowillardiine $(1 \mathrm{~mm})$ produced a much smaller peak current than a control application (Fig. 8A).

A similar relationship was observed between quisqualate and kainate. When kainate was applied during the steady-state current evoked by $100 \mu \mathrm{M}$ quisqualate, the total current induced by quisqualate plus kainate response was reduced compared to kainate alone (Fig. 8B). The kainate dose-response curve ob- 
A

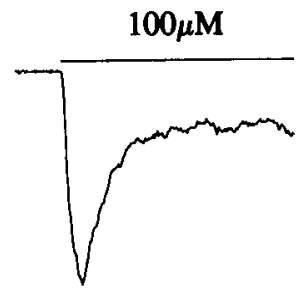

B
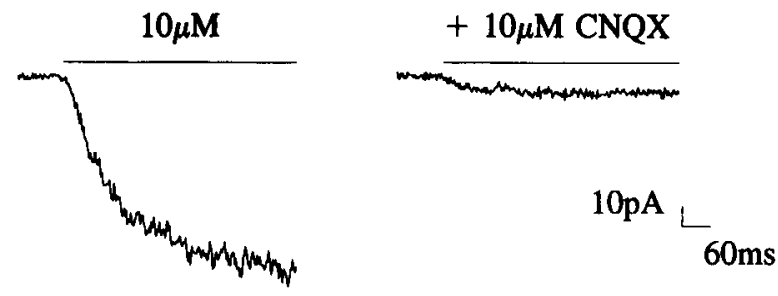

D
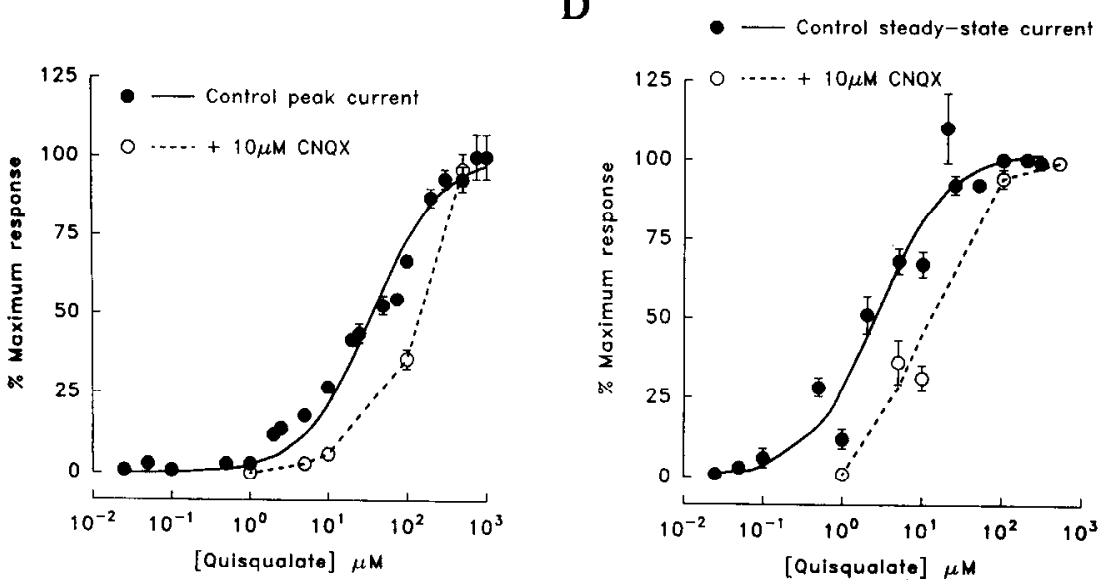

E

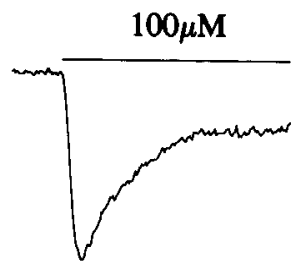

$+10 \mu \mathrm{M} \mathrm{CNQX}$

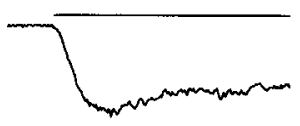

40pA

$60 \mathrm{~ms}$

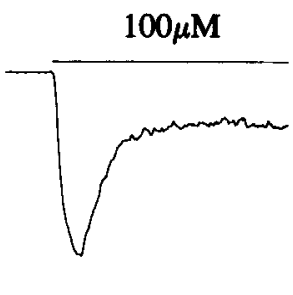

$10 \mu \mathrm{M}$

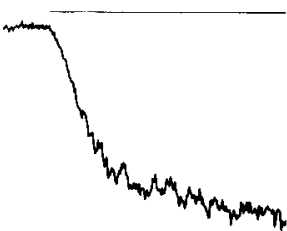

Figure 4. Sensitivity of the peak and steady-state quisqualate currents to excitatory amino acid antagonists. $A$, CNQX $(10 \mu \mathrm{M})$ reversibly blocked the peak current induced by $100 \mu \mathrm{M}$ quisqualate. Traces show successive responses of a neuron at a holding potential of $-50 \mathrm{mV}$ to $100 \mu \mathrm{M}$ quisqualate (left), to $100 \mu \mathrm{M}$ quisqualate plus $10 \mu \mathrm{M}$ CNQX (middle), and to $100 \mu \mathrm{M}$ quisqualate (right). $B, \mathrm{CNQX}(10 \mu \mathrm{M})$ reversibly inhibited the steady-state current evoked by $10 \mu \mathrm{M}$ quisqualate. The protocol is analogous to that in $A$. $C$ and $D, C N Q X(10 \mu \mathrm{M})$ shifts the doseresponse curves for the peak $(C)$ and steady-state $(D)$ quisqualate currents to the right without altering the maximum response. Data points were obtained by expressing the amplitude of the current induced by a given concentration of quisqualate plus $10 \mu \mathrm{M} C N Q X$ as a percentage of the current induced by quisqualate alone at $-50 \mathrm{mV}$. Then, the corresponding point on the control (solid circles) was multiplied by this value. The raw data in the presence of $10 \mu \mathrm{M}$ CNQX (open circles) were then visually fit to the curves shown (broken lines), which gave an $\mathrm{ED}_{50 \text { (pcak,CNQX) }}$ of $200 \mu \mathrm{M}$ and an $\mathrm{ED}_{\text {so(ss,CNOX) }}$ of $20 \mu \mathrm{M}$. Error bars represent \pm SEM, and those not shown are smaller than the symbol $(n=5-19$ for each point). The control data were taken from Figure $3 B . E$, D-APV and $C P P$ did not antagonize the quisqualate response. Traces show responses of a neuron voltage clamped at $-50 \mathrm{mV}$ to $100 \mu \mathrm{M}$ quisqualate (left), $100 \mu \mathrm{M}$ quisqualate $+1 \mathrm{mM}$ D-APV (middle), and $100 \mu \mathrm{M}$ quisqualate $+1 \mathrm{~mm} \mathrm{CPP}($ right $)$.

tained while $100 \mu \mathrm{M}$ quisqualate induced a steady-state current revealed an interaction between the two agonists that was not competitive (Fig. $8 \mathrm{C}$ ). By itself, kainate activated a nondesensitizing current in a concentration-dependent manner with an $\mathrm{ED}_{50 \text { (kainate) }}$ of $300 \mu \mathrm{M}$ and a Hill coefficient of $1.2 \pm 0.1$. When the kainate dose-response curve was obtained while $100 \mu \mathrm{M}$ quisqualate elicited a steady-state current, the maximum response attainable was reduced and the $\mathrm{ED}_{50(\text { (kainate,pre }}$ was $300 \mu \mathrm{M}$. In contrast, applying kainate and $10 \mu \mathrm{M}$ quisqualate simultaneously unveiled an apparently competitive interaction between the two agonists (Fig. 8D,E). The dose-response curve for kainate acquired in this manner was shifted to the right with no change in the maximum response. In this case, the $\mathrm{ED}_{50 \text { (kainate,co) }}$ was $1 \mathrm{~mm}$.
The reduction in the maximum kainate response in the presence of $100 \mu \mathrm{M}$ quisqualate may reflect the desensitization of at least some kainate receptors by quisqualate. This possibility was further examined in neurons bathed in $580 \mathrm{nM}$ WGA, a lectin that blocks quisqualate receptor desensitization (Zorumski et al., 1990). In these neurons, the steady-state response to $1 \mathrm{~mm}$ kainate was $110 \pm 9 \%(n=7)$ of the steady-state response to $100 \mu \mathrm{M}$ quisqualate compared to $1400 \pm 240 \%(n=7)$ in control neurons (Fig. $8 E, F$ ). Furthermore, the response to an application of $1 \mathrm{mM}$ kainate plus $100 \mu \mathrm{M}$ quisqualate was $110 \pm 8 \%(n=$ 7) of the response to $100 \mu \mathrm{M}$ quisqualate alone and $110 \pm 6 \%$ $(n=7)$ of the response to $1 \mathrm{~mm}$ kainate alone (Fig. $8 F)$. Consistent with these results, applying $1 \mathrm{~mm}$ kainate during the steady-state current to $100 \mu \mathrm{M}$ quisqualate produced a total 
A

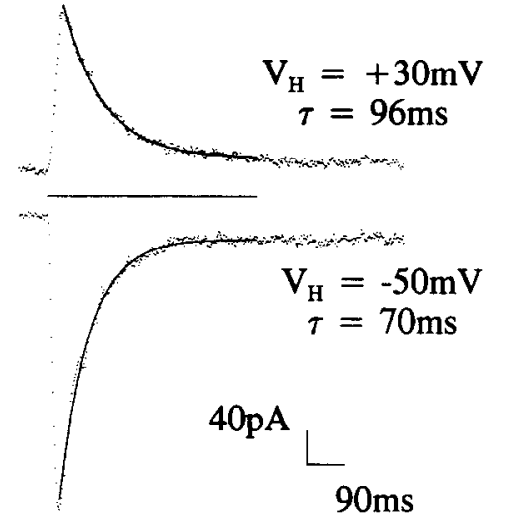

Figure 5. Concentration and voltage dependence of quisqualate receptor desensitization. $A$, Response of a neuron at holding potentials of $+30 \mathrm{mV}$ (top) and $-50 \mathrm{mV}$ (bottom) to $100 \mu \mathrm{M}$ quisqualate. Decays of raw data (dotted traces) were fit to single exponential functions (solid traces) with time constants of $96 \mathrm{msec}$ at $+30 \mathrm{mV}$ and 70 msec at $-50 \mathrm{mV}$. $B$, Dependence of $\tau_{d}$ on quisqualate concentration. $\tau_{d}$ for 100 $\mu \mathrm{M}$ quisqualate (hatched bars) was compared to $\tau_{d}$ for a test quisqualate concentration (open bars) in a single neuron voltage clamped at $-50 \mathrm{mV}$. $\tau_{d}$ for each test concentration was compared to that for $100 \mu \mathrm{M}$ quisqualate in the same set of neurons using a two-tailed paired $t$ test. Only the $\tau_{d}$ for $10 \mu \mathrm{M}$ was significantly different from that of $100 \mu \mathrm{M}(p$ $<0.05$ ). The bar at the far right shows the $\tau_{d}$ for $100 \mu \mathrm{M}$ in a series of $37 \mathrm{neu}-$ rons. $C$ and $D$, Dependence of $\tau_{d}(C)$ and percent desensitization $(D)$ on quisqualate concentration and voltage. $\tau_{d}$ and the $\%$ desensitization for $20 \mu \mathrm{M}$ quisqualate (open bars) were compared to $\tau_{d}$ and the percent desensitization for $100 \mu \mathrm{M}$ quisqualate (hatched bars) in five neurons at the potentials indicated. *, Paired two-tailed $t$ test compared to $100 \mu \mathrm{M}$ quisqualate at the same potential, $p<0.05$. **, Paired two-tailed $t$ test compared to the same concentration of quisqualate at $+70 \mathrm{mV}, p<$ 0.05 . Error bars in $B-D$ represent \pm SEM.

$\mathrm{C}$
B
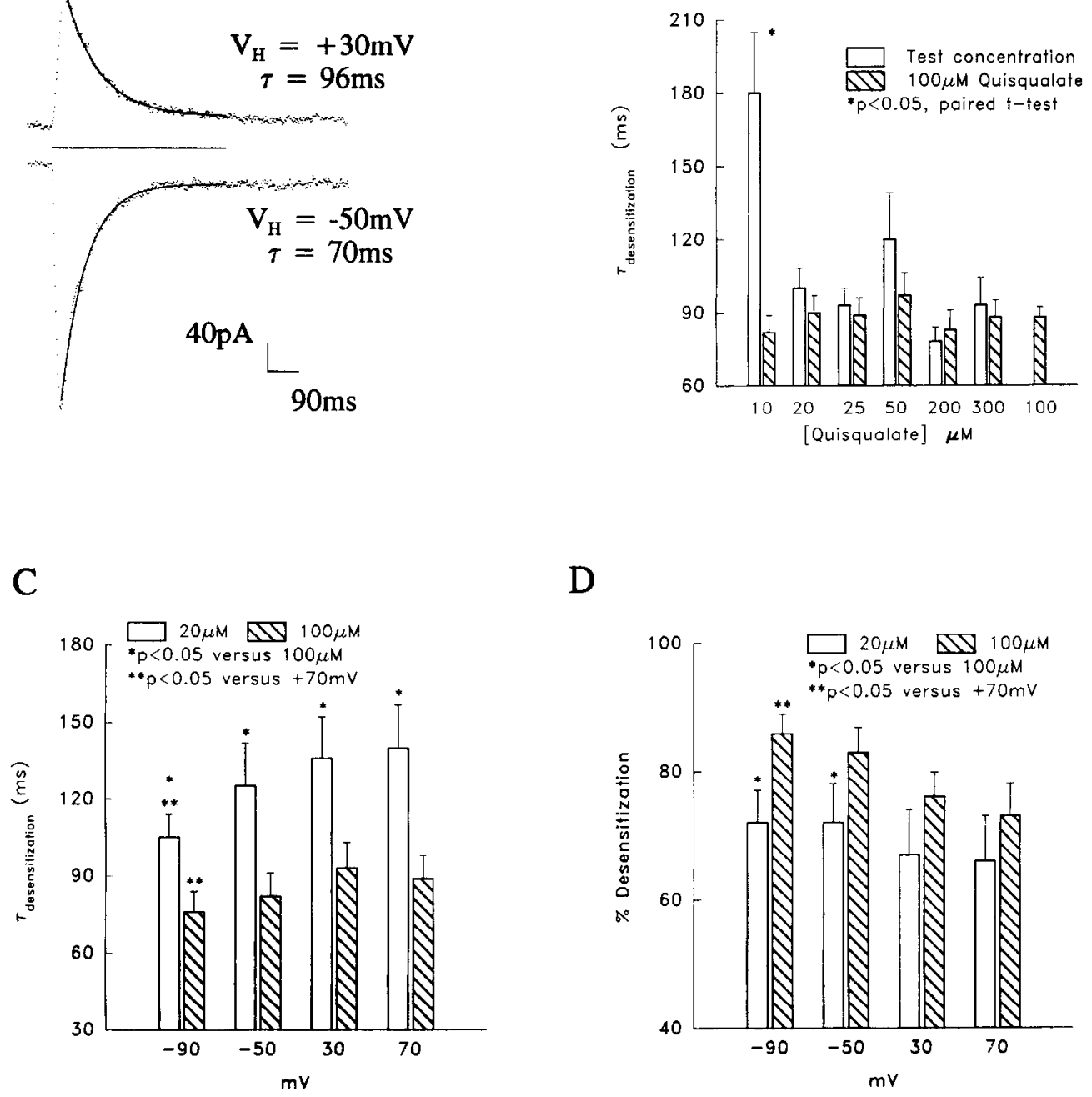

$\mathrm{D}$

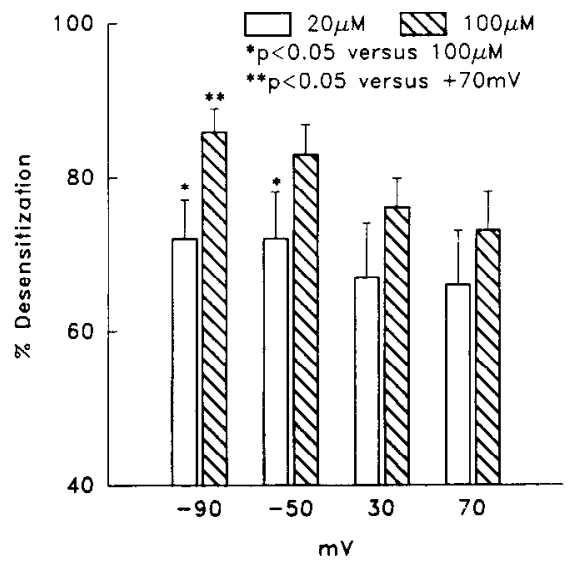

current that was $94 \pm 8 \%(n=7)$ of the current to $100 \mu \mathrm{M}$ quisqualate alone and $96 \pm 9 \%(n=7)$ of the current to $1 \mathrm{~mm}$ kainate alone.

\section{Discussion}

An ionotropic quisqualate receptor mediates the rapidly desensitizing quisqualate response

Quisqualate and glutamate evoked a rapidly desensitizing current that decayed to a steady-state level in cultured postnatal rat hippocampal neurons. Both the peak and the steady-state currents were activated by quisqualate in a concentration-dependent manner, and both had a linear $I / V$ relationship in the presence of extracellular $\mathrm{Mg}^{2+}$. For the steady-state current, a linear $I / V$ relationship was found in the presence of extracellular $\mathrm{Mg}^{\text {?+ }}$ when determincd using the "instantaneous" but not the "steady-state" method. The reason for the nonlinear "steadystate $I / V$ ' is unknown but does not reflect a contribution by NMDA receptors. The near $0 \mathrm{mV}$ reversal potential for both currents suggests that they are mediated by a nonselective cationic conductance. Accordingly, quisqualate elicited an inward peak and steady-state current at negative holding potentials when both extracellular and intracellular $K^{\prime}\left(\mathrm{Cs}^{\prime}\right)$ was replaced with $\mathrm{Na}^{+}$or vice versa. Both currents were inhibited by CNQX, a competitive non-NMDA antagonist, but not by D-APV and CPP, competitive NMDA antagonists. In addition, other nonNMDA analogs such as AMPA, BOAA, 4-methyl-homoibotenic acid, willardiine, and 5-bromowillardiine, which are all structurally related to quisqualate, induced similar responses capable of cross-desensitizing quisqualate responses. Of all the quisqualate analogs tested, only trans-ACPD, which activates the metabotropic quisqualate receptor, did not activate a current under the conditions used in this study. These results suggest that both the peak and steady-state currents are mediated by a nonselective cationic, ionotropic quisqualate receptor.

The characteristics of the quisqualate response in cultured hippocampal neurons from 1-3 d postnatal rats are most similar to those from acutely dissociated hippocampal neurons from 2-3-week-old rats (Kiskin et al., 1986, 1990). The $\mathrm{ED}_{50(\text { peak) }}$, Hill coefficient for the peak current, $\tau_{d}$, and $\mathrm{ED}_{50 \text { (ss desensitization) }}$ in these two preparations are comparable. Although an $\mathrm{ED}_{50(s s)}$ was not reported in these studies, the $\mathrm{ED}_{50 \text { (ss) }}$ is 10 -fold lower than the $\mathrm{ED}_{\text {s0(peak) }}$ in embryonic hippocampal neurons (Tang et al., 1989; Patneau and Mayer, 1990). Another preparation exhibiting a rapidly decaying quisqualate response that shares many characteristics with the response described here is retinal horizontal cells (O'Dell and Christensen, 1989a,b). The lower Hill coeffi- 
A

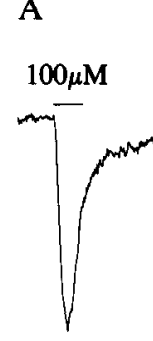

B

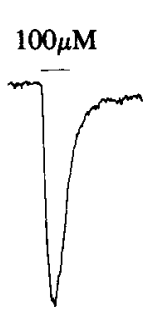

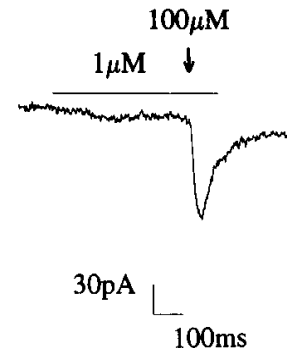
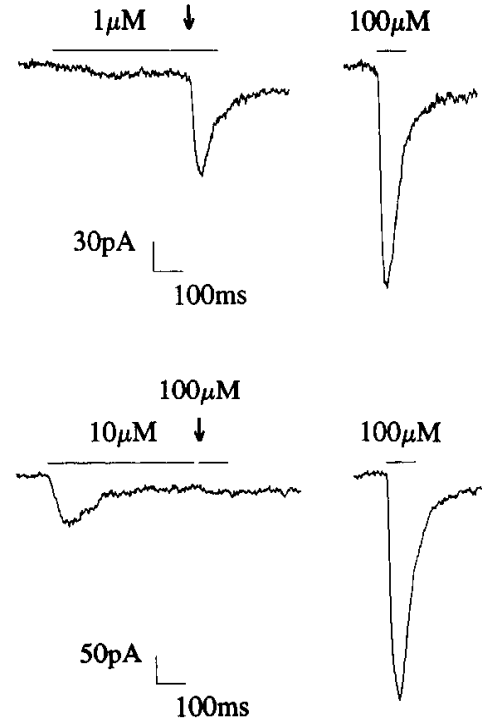

$100 \mu \mathrm{M}$

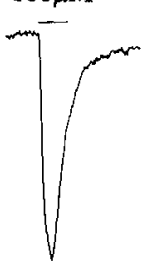

$\mathrm{C}$

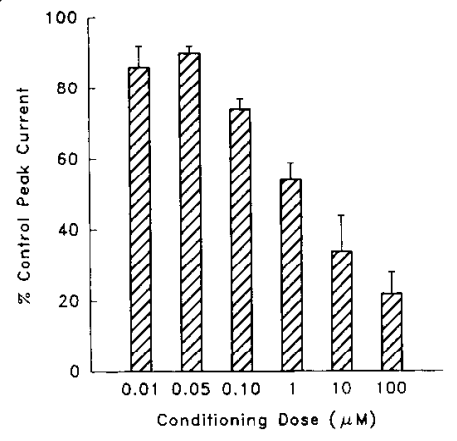

Figure 6. Desensitization of quisqualate receptors by conditioning doses of quisqualate. $A$ and $B$, Response of a neuron at a holding potential of $-50 \mathrm{mV}$ to an application of $100 \mu \mathrm{M}$ quisqualate (left), application of a conditioning dose of $1 \mu \mathrm{M}(A)$ or $10 \mu \mathrm{M}(B)$ quisqualate followed by a challenge to $100 \mu \mathrm{M}$ quisqualate beginning at arrow (middle), and recovery of $100 \mu \mathrm{M}$ quisqualate response (right). $C$, Effect of conditioning doses of quisqualate on the peak current evoked by $100 \mu \mathrm{M}$ quisqualate at $-50 \mathrm{mV}$. The percent control peak current was determined by applying a 100 msec test pulse of $100 \mu \mathrm{M}$ quisqualate. After the neuron recovered, a conditioning dose was applied for $500 \mathrm{msec}$, and $25 \mathrm{msec}$ later another 100 msec test pulse was applied. Although $25 \mathrm{msec}$ elapsed between the end of the conditioning pulse and the test pulse, the conditioning dose should not have dissipated by much since these experiments were performed in a static bath. The peak current of the test pulse after the conditioning pulse as measured from the original baseline was then expressed as a percentage of the control peak current. Because the steady-state current induced by the conditioning dose was included in the measurement, the percent control peak current was not zero when the conditioning dose was $100 \mu \mathrm{M}$. However, in all cells examined, no additional current was evoked by the test pulse when a $100 \mu \mathrm{M}$ conditioning dose was used. Error bars show \pm SEM ( $n=5-6$ for each conditioning dose).

cient is the most conspicuous discrepancy between our results and some of the other studies. The Hill coefficient is $\geq 1.5$ for the peak current in horizontal cells and is $\geq 1.5$ for the steadystate current in embryonic mouse hippocampal neurons. The reason for these differences is unclcar, but the two preparations may have different receptor-channel complexes since they are derived from different species and developmental stages. Interestingly, the quisqualate response in chick spinal cord neurons changes during embryogenesis (Baev et al., 1990).

\section{A channel block mechanism does not cause quisqualate receptor desensitization}

The decay in the quisqualate current may be caused by an ion or other substance blocking the pore of the quisqualate channel. However, a critical role for extracellular $\mathrm{Na}^{+}, \mathrm{K}^{+}, \mathrm{Ca}^{2+}$, or $\mathrm{Mg}^{2+}$ in producing the decay is unlikely since the decay of the response in the presence of these ions was similar to that in their nominal absence. Another ion that remains a candidate as a blocker of quisqualate-gated channels is $\mathrm{H}^{+}$, though $\mathrm{pH}$ changes in the range of 6.3-8.3 have no effect on quisqualate responses in embryonic hippocampal neurons (Tang ct al., 1990; Vyklický et al., 1990).

Other potential blockers include quisqualate and glutamate (Vlachová et al., 1987), which, like ACh and some of its analogs (Adams and Sakmann, 1978; Trautmann, 1982; Sine and Steinbach, 1984), may block the channels they gate. While agonist blockade of nicotinic $\mathrm{ACh}$ receptor (nAChR) channels is strongly influenced by voltage, the weak voltage dependence of quisqualate receptor desensitization does not dismiss this model since the block of $\mathrm{nAChR}$ channels by some barbiturates is not voltage dependent (Adams, 1976). In fact, the marked decay observed at negative holding potentials would suggest a weakly voltage dependent block since quisqualate and glutamate have a net negative charge at physiological pH (Boden et al., 1986). If the decay reflects blockade of the channel by quisqualate or glutamate, then these molecules may bind to the vestibule of the channel, or a neutral portion of the molecule, such as the zwitterionic part, may be responsible for the block (Ishida and Neyton, 1985).

While the decay of the quisqualate current may reflect the blockade of the channel by quisqualate itself, several observations are inconsistent with quisqualate acting as a simple open channel blocker according to the model

$$
Q+R \leftrightharpoons Q R \leftrightharpoons Q R_{o}+Q \leftrightharpoons Q R_{o} Q
$$

where $Q$ represents quisqualate, $R$ represents the quisqualate receptor-channel complex, $Q R$ represents the bound but closed receptor-channel complex, $Q R_{o}$ represents the open receptorchannel complex, and $Q R_{o} Q$ represents the open but blocked receptor-channel complex. This model predicts that $\tau_{d}$ would decrease linearly with increasing quisqualate concentration. It also predicts that magnitude of the steady-state current would decrease with increasing quisqualate concentration assuming the steady-state current is produced by unblocked channels alone. However, both $\tau_{d}$ and the steady-state current remained constant at concentrations above $20 \mu \mathrm{M}$. Finally, although the mean burst duration of the channel would be expected to increase with increasing quisqualate concentration according to this model 
Figure 7. Quisqualate receptor desensitization did not require extracellular $\mathrm{Ca}^{2+}, \mathrm{Mg}^{2+}, \mathrm{K}^{+}$, or $\mathrm{Na}^{+}$. $A$, Response induced by $100 \mu \mathrm{M}$ quisqualate in a neuron bathed in an extracellular solution containing no added $\mathrm{Ca}^{2+}$ or $\mathrm{Mg}^{2+}$; $200 \mu \mathrm{M}$ D,L-APV was added to prevent neuronal swelling. $B$, Response evoked by $100 \mu \mathrm{M}$ quisqualate in a neuron bathed in an extracellular solution containing no added $\mathrm{K}^{+}$. Both the $\mathrm{KCl}$ in the extracellular solution and the $\mathrm{CsCl}$ in the pipette solution were replaced with an equimolar concentration of $\mathrm{NaCl}\left([\mathrm{NaCl}]_{\text {out }}=[\mathrm{NaCl}]_{\text {in }}=145 \mathrm{~mm}\right)$. $C$, Response elicited by $100 \mu \mathrm{M}$ quisqualate in a neuron bathed in an extracellular solution containing no added $\mathrm{Na}^{+}$. The $\mathrm{NaCl}$ in the extracellular and pipette solutions was substituted with $\mathrm{CsCl}\left([\mathrm{CsCl}]_{\text {out }}=[\mathrm{CsCl}]_{\text {in }}=145 \mathrm{~mm}\right)$. Records in $A-C$ were taken from neurons voltage clamped at $-50 \mathrm{mV} . D$ and $E$, Dependence of $\tau_{d}(D)$ and percent desensitization $(E)$ on quisqualate concentration and voltage in the absence of $\mathrm{Mg}^{2+}, \tau_{d}$ and the percent desensitization for $20 \mu \mathrm{M}$ (open bars) and $100 \mu \mathbf{M}$ (hatched bars) quisqualate were measured in three neurons at the indicated potentials. Neurons were bathed in an extracellular solution containing $3 \mathrm{mM} \mathrm{CaCl}_{2}$ and no added $\mathrm{Mg}^{2+}$. *, Paired two-tailed $t$ test compared to 100 $\mu \mathrm{M}$ quisqualate at the same voltage, $p$ $<0.05$. ${ }^{* *}$, Paired two-tailed $t$ test compared to the same quisqualate concentration at $+70 \mathrm{mV}, p<0.05$. $F$ and $G$, Dependence of $\tau_{d}(F)$ and the percent desensitization $(G)$ on quisqualate concentration and voltage when $\mathrm{Na}^{+}$is the only monovalent cation present. $\tau_{d}$ and the percent desensitization for $20 \mu \mathrm{M}$ (open bars), $100 \mu \mathrm{M}$ (hatched bars), and $300 \mu \mathrm{M}$ (crosshatched bars) quisqualate were measured in three neurons at the voltages listed. The composition of the extracellular and pipette solutions was as in $B .^{*}$, Paired two-tailed $t$ test compared to $300 \mu \mathrm{M}$ quisqualate at the same potential, $p<0.05$. $^{* *}$, Paired two-tailed $t$ test compared to the same quisqualate concentration at $+70 \mathrm{mV}, p<0.05$. All error bars depict \pm SEM.
A

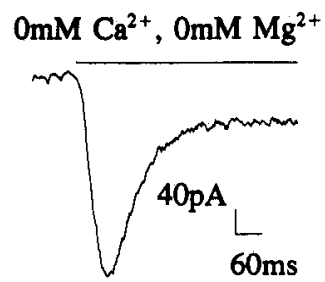

B

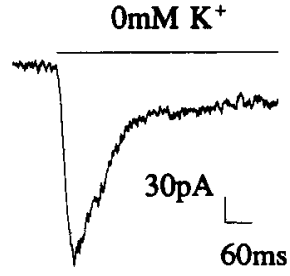

C

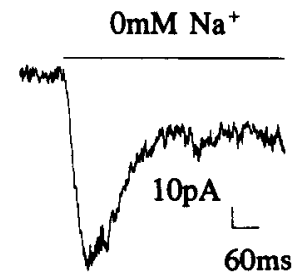

D

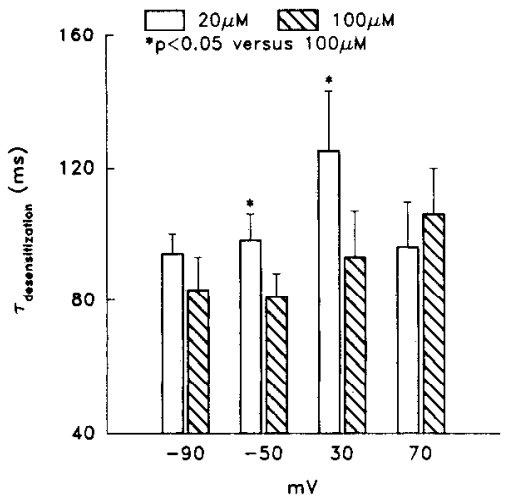

F

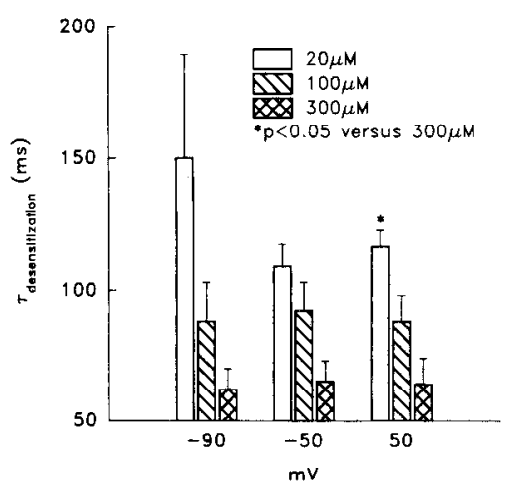

$\mathrm{E}$

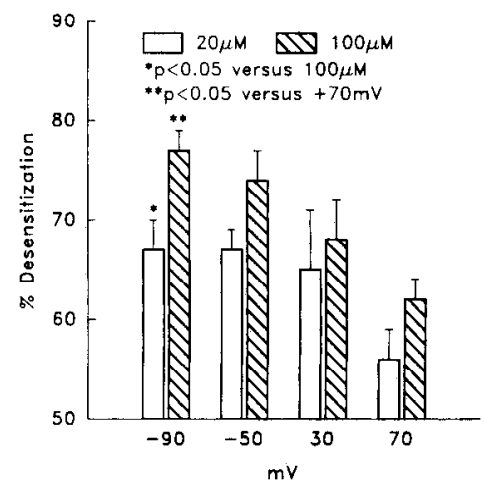

$\mathbf{G}$

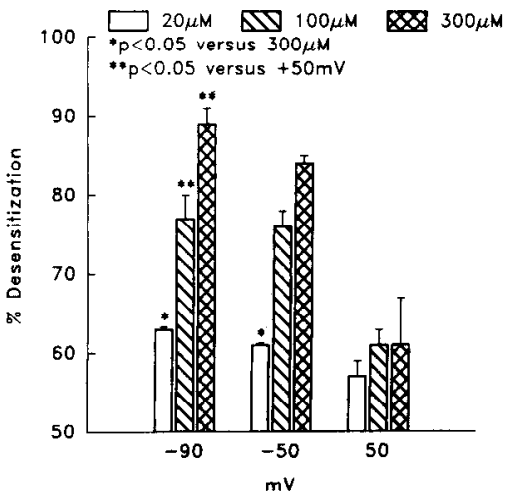

(Neher and Steinbach, 1978), the mean burst duration showed little dependence on quisqualate concentration over the range 2.5-1000 $\mu \mathrm{M}$ (Thio ct al., 1990).

\section{Relationship between the steady-state and peak quisqualate currents}

Concentrations of quisqualate near $1 \mu \mathrm{M}$ (Fig. 6C) desensitized the peak current by $\sim 50 \%$ while the $\mathrm{ED}_{\text {so(peak) }}$ was $40 \mu \mathrm{M}$. There- fore, quisqualate was $\sim 40$ times more potent in desensitizing the peak current in cultured postnatal rat hippocampal neurons than it was in activating it. Similarly, both glutamate and quisqualate in rat hippocampal neurons from 2-week-old rats (Kiskin et al., 1986, 1990) and glutamate in cultured chick spinal cord neurons (Trussell and Fischbach, 1989) are 50-100 times more potent in desensitizing receptors than in activating them. However, in these latter studies, doses capable of desensitizing

Figure 8. Interaction between non-NMDA analogs. $A$, Cross-desensitization between non-NMDA agonists: response of a neuron to $100 \mu \mathrm{M}$ quisqualate applied at arrow (left), application of $1 \mathrm{mM}$ BOAA followed by a challenge to $100 \mu \mathrm{M}$ quisqualate (middle), and recovery of $100 \mu \mathrm{M}$ quisqualate response (right). All agonist applications were $500 \mathrm{msec}$. $R$, Desensitization of kainate responses hy quisqualate: response of a neuron to $1 \mathrm{~mm}$ kainate applied at arrow (left), application of $100 \mu \mathrm{M}$ quisqualate followed by an application of 1 mM kainate (middle), and recovery of 1 mм kainate response (right). All agonist applications were $100 \mathrm{msec}$. Vertical calibration, $200 \mathrm{pA}$. Horizontal calibration: left and right, 10 sec; 
A

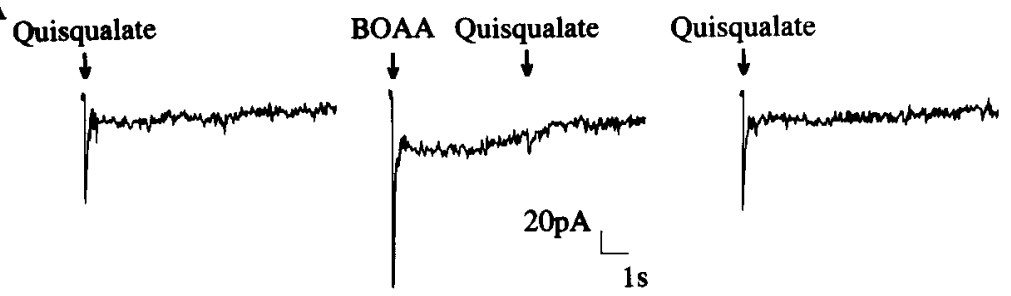

B
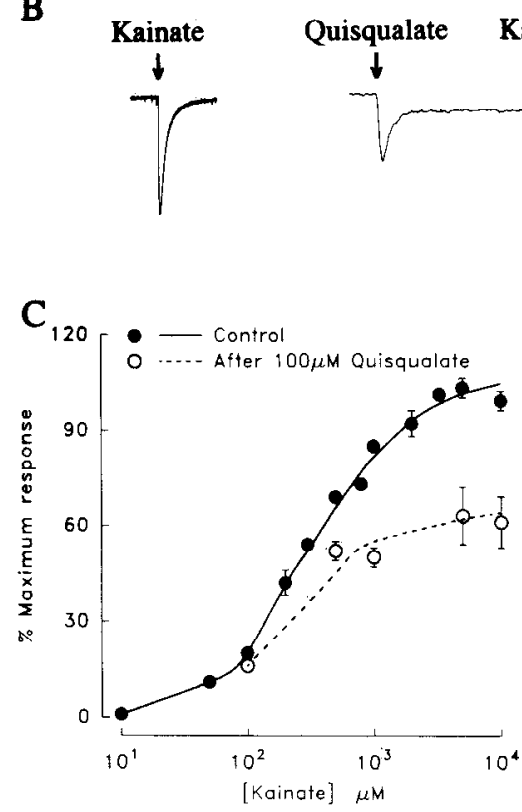
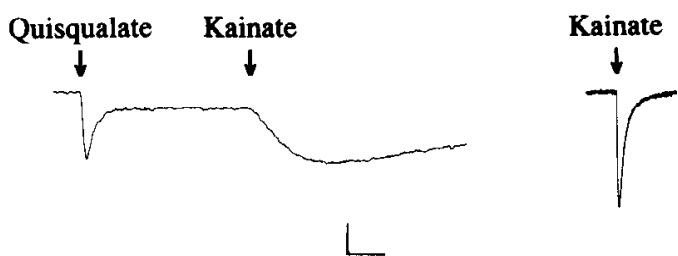

$\mathrm{E}$
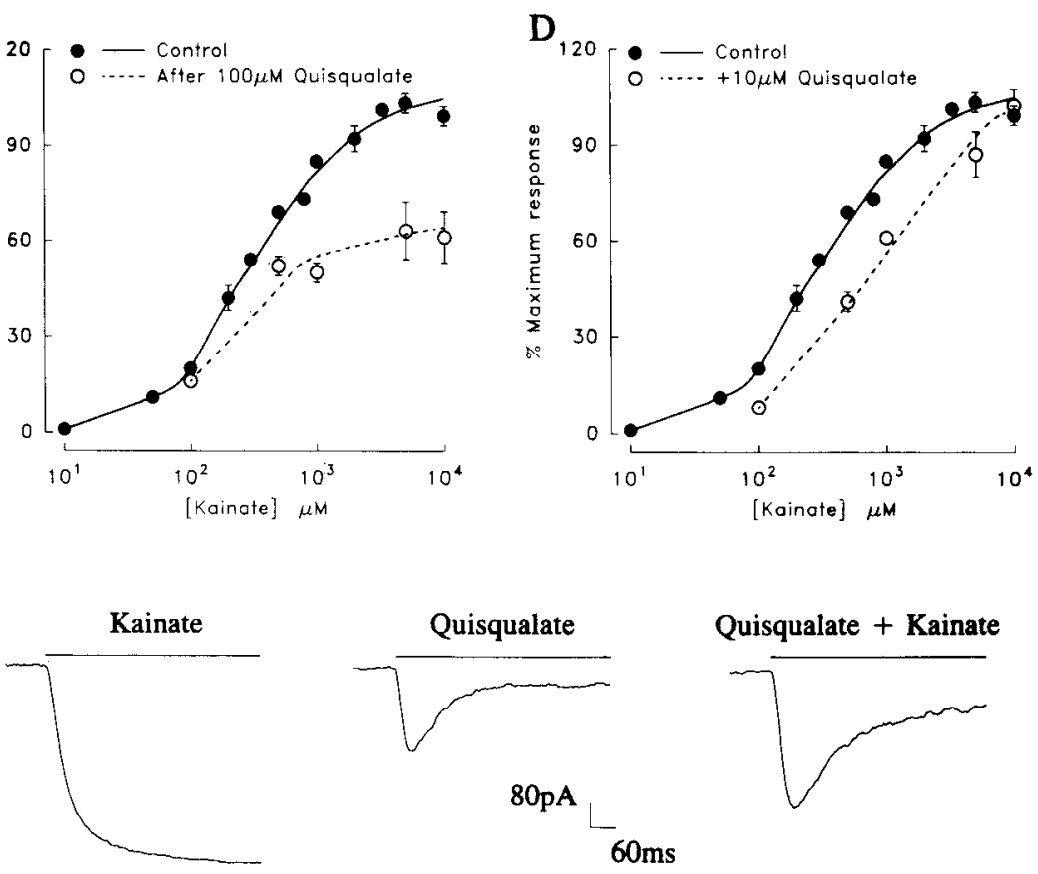

Quisqualate + Kainate

F
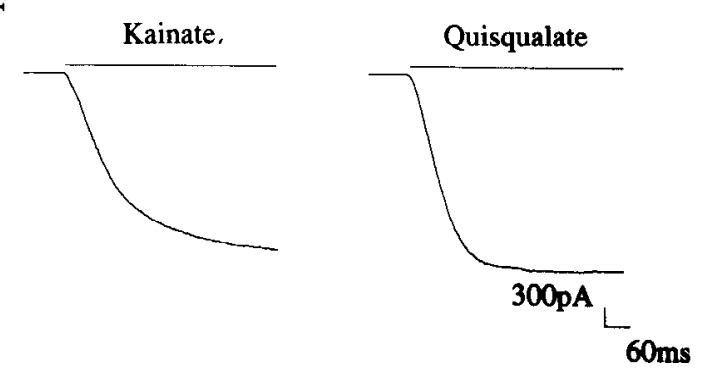

Quisqualate + Kainate

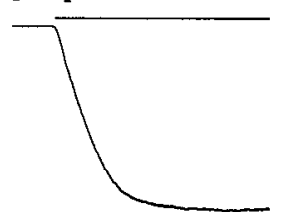

middle, $400 \mathrm{msec}$. $C$, Interaction between kainate and quisqualate when quisqualate is preapplied. The control kainate dose-response curve was generated by normalizing the amplitude of the peak current induced by a test kainate concentration to that induced by 1 mm kainate in a single neuron. Raw data (solid circles) were fit visually (solid curve) to estimate the $\mathrm{ED}_{50(\text { (kainate) }}$, which was $300 \mu \mathrm{M}$. The kainate dose-response curve was then repeated using the paradigm in $B$. The amplitude of the current induced by a test kainate concentration during the steady-state current produced by $100 \mu \mathrm{M}$ quisqualate was measured from the original baseline and expressed as a percentage of the current induced by the test concentration alone. This value was then multiplied by the corresponding point on the control dose-response curve (open circles). These points were then fitted visually (broken curve) and yielded an $\mathrm{ED}_{50(\text { kainatepre) }}$ of $300 \mu \mathrm{M} . D$, Coapplication of quisqualate shifts the kainate dose-response curve to the right without altering the maximum response. The amplitude of the peak current produced by a test kainate concentration plus $10 \mu \mathrm{M}$ quisqualate was expressed as a percentage of the peak current produced by $1 \mathrm{~mm}$ kainate in the same neuron (open circles). These data were visually fit to the curve shown (broken curve) with an ED $\mathrm{ED}_{\text {sonate oo }}$ of $1 \mathrm{~mm}$. Control kainate dose-response curve (solid circles and solid curve) are as in $C$. Error bars in $C$ and $D$ represent $\pm \mathrm{SEM}$, and those not shown are smaller than the symbol ( $n=4-15$ for each point). $E$ and $F$. Interaction between kainate and quisqualate when coapplied: response of a neuron to $1 \mathrm{~mm}$ kainate (left), $100 \mu \mathrm{M}$ quisqualate (middle), and 1 mM kainate plus $100 \mu \mathrm{M}$ quisqualate (right) in the absence $(E)$ and presence $(F)$ of $580 \mathrm{~nm}$ WGA in the extracellular solution. All data in this figure were obtained at $-50 \mathrm{mV}$. 
receptors do not appear to evoke a current, whereas a steadystate current was activated by such doses in our cultured postnatal rat hippocampal neurons. The difference in these results may reflect the relatively small size of the steady-state current in these other studies.

The difference in potency between desensitization and activation has led to the suggestion that quisqualate channels can desensitize without opening (Trussell and Fischbach, 1989) and that separate activation and desensitization sites exist (Kiskin et al., 1990). In our study, conditioning doses of quisqualate that failed to activate a steady-state current drove $\sim 10 \%$ of the receptors into the desensitized state (Fig. $6 \mathrm{C}$ ). The majority of receptors, however, were not desensitized until concentrations large enough to evoke a clear steady-state current were administered. The overlap between the dose-response curves for desensitizing the peak current and activating the steady-state current suggests that the two processes are related. This overlap also suggests that the peak and steady-state currents are mediated by the same receptors. If they reflect the activation of the same receptors, then the two currents are likely to be different states of the receptor since the $\mathrm{ED}_{5 \text { (peak) }}$ is 10 -fold greater than the $\mathrm{ED}_{50(\mathrm{ss})}$. This difference in $\mathrm{ED}_{50}$ values is unlikely to be accounted for by an underestimate in the peak current since the $\mathrm{ED}_{50 \text { (peak) }}$ is not reduced by 10 -fold when desensitization is blocked by WGA (40 $\mu \mathrm{M}$ in control neurons vs $30 \mu \mathrm{M}$ in WGA-treated neurons). However, our data do not exclude the existence of a separate desensitizing site having a dose-response curve comparable to that for the steady-state current. In this model, the steady-state current could be mediated by a separate receptorchannel complex from the peak current.

\section{Relationship between quisqualate and kainate receptors}

Previous studies have established that overlap exists between quisqualate and kainate receptor-channel complexes, though the extent of the overlap is unknown. A competitive interaction between quisqualate and kainate is observed when the two agonists are coapplied (O'Brien and Fischbach, 1986; Zorumski and Yang, 1988; O'Dell and Christensen, 1989a,b; Perouansky and Grantyn, 1989; Pin et al., 1989; Rassendren et al., 1989). In contrast, uncompetitive interaction is found when quisqualate is applied after kainate (Ishida and Neyton, 1985), and quisqualate desensitizes kainate responses when the order of application is reversed (Kiskin et al., 1986, 1990). These results were confirmed in our study. Quisqualate and kainate appeared to interact competitively when cuapplied to postnatal rat hippocampal neurons and noncompetitively when quisqualate is applied first. In addition, saturating concentrations of kainate and quisqualate produced responses of equal amplitude in neurons bathed in WGA. The response to either agonist alone equaled the response to a coapplication of saturating concentrations of kainate and quisqualate in WGA-treated neurons. Finally, as might be expected, saturating concentrations of kainate induce no additional current when a saturating concentration of quisqualate is applicd first in a WGA-trcated neuron. The results from WGA-treated neurons suggest that the apparently noncompetitive interaction in control neurons between kainate and quisqualate when the latter is preapplied results from the desensitization of some kainate receptors by quisqualate. All the observations taken together are consistent with the hypothesis proposed earlier (Kiskin et al., 1986, 1990) that kainate and quisqualate activate the same receptor-channel complexes but kainate is incapable of desensitizing them. Thus, desensitization of the complex may be agonist specific. In agreement with these results, the quisqualate receptor clones respond to both quisqualate and kainate (Boulter et al., 1990; Keinänen et al., 1990). The relationship between the quisqualate and kainate receptorchannel complexes should be better defined as work with the quisqualate receptor clones progresses.

\section{References}

Adams PR (1976) Drug blockade of open end-plate channels. J Physiol (Lond) 260:531-552.

Adams PR, Sakmann B (1978) Decamethonium both opens and blocks endplate channels. Proc Natl Acad Sci USA 75:2994-2998.

Baev KV, Rusin KI, Safronov BV (1990) Development of L-glutamateand glycine-activated currents in spinal cord neurones during carly chick embryogenesis. J Physiol (Lond) 423:381-395.

Barres BA, Koroshetz WJ, Swartz KJ, Chun LLY, Corey DP (1990) Ion channel expression by white matter glia: the $\mathrm{O}-2 \mathrm{~A}$ glial progenitor cell. Neuron 4:507-524.

Boden P, Bycroft BW, Chhabra SR, Chiplin J, Crowley PJ, Grout RJ, King TJ, McDonald E, Rafferty P, Usherwood PNR (1986) The action of natural and synthetic isomers of quisqualic acid at welldefined glutamatergic synapse. Brain Res 385:205-211.

Boulter J, Hollmann M, O'Shea-Greenfield A, Hartley M, Deneris E, Maron C, Heinemann S (1990) Molecular cloning and functional expression of glutamate receptor subunit genes. Science 249:10331037.

Choi DW (1988) Glutamate neurotoxicity and diseases of the nervous system. Neuron 1:623-634.

Clark GD, Clifford DB, Zorumski CF (1990) The effect of agonist concentration, membrane voltage and calcium on $N$-methyl-D-aspartate receptor desensitization. Neuroscience 39:787-797.

Collingridge GL, Lester RAJ (1989) Excitatory amino acid receptors in the vertebrate central nervous system. Pharmacol Rev 40:143-210.

Collingridge GL, Singer W (1990) Excitatory amino acid receptors and synaptic plasticity. Trends Pharmacol Sci 11:290-296.

Davies SN, Lester RAJ, Reymann KG, Collingridge GL (1989) Temporally distinct pre- and post-synaptic mechanisms maintain longterm potentiation. Nature 338:500-503.

Hamill OP, Marty A, Neher E, Sakmann B, Sigworth FJ (1981) Improved patch-clamp techniques for high-resolution current recording from cells and cell-free membrane patches. Pfluegers Arch 391:85100 .

Huettner JE (1990) Glutamate receptor channels in rat DRG neurons: activation by kainate and quisqualate and blockade of desensitization by Con $A$. Neuron 5:255-266.

Ishida AT, Neyton J (1985) Quisqualate and L-glutamate inhibit retinal horizontal-cell responses to kainate. Proc Natl Acad Sci USA 82: 1837-1841.

Ito M (1986) Long-term depression as a memory process in the cerebellum. Neurosci Res 3:531-539.

Kano M, Kato M (1987) Quisqualate receptors are specifically involved in cerebellar synaptic plasticity. Nature 325:276-279.

Kauer JA, Malenka RC, Nicoll RA (1988) A persistent postsynaptic modification mediates long-term potentiation in the hippocampus. Neuron 1:911-917.

Keinänen K, Wisden W, Sommer B, Werner P, Herb A, Verdoorn TA, Sakmann B, Seeburg PH (1990) A family of AMPA-selective glutamate receptors. Science 249:556-560.

Kiskin NI, Krishtal OA, Tsyndrenko AYa (1986) Excitatory amino acid receptors in hippocampal neurons: kainate fails to desensitize them. Neurosci Lett 63:225-230.

Kiskin NI, Krishtal OA, Tsyndrenko AYa (1990) Cross-desensitization reveals pharmacological specificity of excitatory amino acid receptors in isolated hippocampal neurons. Fur J Neurosci 2:461-470.

Mayer ML, Vyklicky L Jr (1989) Concanavalin A selectively reduces desensitization of mammalian neuronal quisqualate receptors. Proc Natl Acad Sci USA 86:1411-1415.

Mayer ML, Westbrook GL (1985) The action of $N$-methyl-D-aspartic acid on mouse spinal neurones in culture. J Physiol (Lond) 361:6590.

Mayer ML, Westbrook GL (1987) The physiology of excitatory amino acids in the vertebrate central nervous system. Prog Neurobiol 28 197-276.

McDonald JW, Johnston MV (1990) Physiological and pathophysi- 
ological roles of excitatory amino acids during central nervous system development. Brain Res Rev 15:41-70.

Meldrum B, Garthwaite J (1990) Excitatory amino acid neurotoxicity and neurodegenerative disease. Trends Pharmacol Sci 11:379-387.

Monaghan DT, Bridges RJ, Cotman CW (1989) The excitatory amino acid receptors: their classes, pharmacology, and distinct properties in the function of the central nervous system. Annu Rev Pharmacol Toxicol 29:365-402.

Muller D, Lynch G (1988) Long-term potentiation differentially affects two components of synaptic responses in hippocampus. Proc Natl Acad Sci USA 85:9346-9350.

Muller D, Joly M, Lynch G (1988) Contributions of quisqualate and NMDA receptors to the induction and expression of LTP. Science 242:1694-1697.

Neher E, Steinbach JH (1978) Local anaesthetics transiently block currents through single acetylcholine-receptor channels. J Physiol (Lond) 277:153-176.

O'Brien RJ, Fischbach GD (1986) Characterization of excitatory amino acid receptors expressed by embryonic chick motoneurons in vitro. J Neurosci 6:3275-3283.

Ochoa ELM, Chattopadhyay A, McNamee MG (1989) Desensitization of the nicotinic acetylcholine receptor: molecular mechanisms and effect of modulators. Cell Mol Neurobiol 9:141-178.

O'Dell TJ, Christensen BN (1989a) A voltage-clamp study of isolated stingray horizontal cell non-NMDA excitatory amino acid receptors. J Neurophysiol 61:162-172.

O'Dell TJ, Christensen BN (1989b) Horizontal cells isolated from catfish retina contain two types of excitatory amino acid receptors. J Neurophysiol 61:1097-1109.

Patneau DK, Mayer ML (1990) Structure-activity relationships for amino acid transmitter candidates acting at $N$-methyl-D-aspartate and quisqualate receptors. J Neurosci 10:2385-2399.

Perouansky M, Grantyn R (1989) Separation of quisqualate- and kainate-selective glutamate receptors in cultured neurons from the rat superior colliculus. J Neurosci 9:70-80.

Pin J-P, Van Vliet BJ, Bockaert J (1989) Complex interaction between quisqualate and kainate receptors as revealed by measurement of GABA release from striatal neurons in primary culture. Eur J Pharmacol 172:81-91.

Rassendren F-A, Lory P, Pin J-P, Bockaert J, Nargeot J (1989) A specific quisqualate agonist inhibits kainate responses induced in Xenopus oocytes injected with rat brain RNA. Neurosci Lett 99:333-339.
Sine SM, Steinbach JH (1984) Agonists block currents through acetylcholine receptor channels. Biophys J 46:277-283.

Smart TG (1989) Excitatory amino acids: the involvement of second messengers in the signal transduction process. Cell Mol Neurobiol 9: 193-206.

Tang C-M, Dichter M, Morad M (1989) Quisqualate activates a rapidly inactivating high conductance ionic channel in hippocampal neurons. Science 243:1474-1477.

Tang C-M, Dichter M, Morad M (1990) Modulation of the $N$-methylD-aspartate channel by extracellular $\mathrm{H}^{+}$. Proc Natl Acad Sci USA 87: $6445-6449$

Thio LL, Clifford DB, Zorumski CF (1988) Characterization of a rapidly desensitizing glutamate current in cultured postnatal hippocampal pyramidal neurons. Soc Neurosci Abstr 14:1195.

Thio LL, Clifford DB, Zorumski CF (1990) Effect of wheat germ agglutinin on quisqualate channels in cultured postnatal rat hippocampal neurons. Soc Neurosci Abstr 16:547.

Thompson RF (1986) The neurobiology of learning and memory. Science 233:941-947.

Trautmann A (1982) Curare can open and block ionic channels associated with cholinergic receptors. Nature 298:272-275.

Trussell LO, Fischbach GD (1989) Glutamate receptor desensitization and its role in synaptic transmission. Neuron 3:209-218.

Trussell LO, Thio LL, Zorumski CF, Fischbach GD (1988) Rapid desensitization of glutamate receptors in vertebrate central neurons. Proc Natl Acad Sci USA 85:4562-4566.

Vlachová V, Vyklický L, Vyklický L Jr, Vyskočil F (1987) The action of excitatory amino acids on chick spinal cord neurones in culture. $\mathrm{J}$ Physiol (Lond) 386:425-438.

Vyklický L Jr, Vlachová V, Krưšek J (1990) The effect of external pH changes on responses to excitatory amino acids in mouse hippocampal neurones. J Physiol (Lond) 430:497-517.

Watkins JC, Krogsgaard-Larsen P, Honoré T (1990) Structure-activity relationships in the development of excitatory amino acid agonists and competitive antagonists. Trends Pharmacol Sci 11:25-33.

Zorumski CF, Yang J (1988) AMPA, kainate, and quisqualate activate a common receptor-channel complex on embryonic chick motoneurons. J Neurosci 8:4277-4286.

Zorumski CF, Thio LL, Clark GD, Clifford DB (1990) Blockade of desensitization augments quisqualate excitotoxicity in hippocampal neurons. Neuron 5:61-66. 